\title{
POTRET ORGANISASI KEAGAMAAN DAN RESPON TERHADAP DINAMIKA KEHIDUPAN KEBERAGAMAAN DI SALATIGA
}

\author{
Benny Ridwan \\ Mahasiswa Program Doktor UIN Sunan Kalijaga Yogyakarta \\ Email: bennyridwan@stainsalatiga.ac.id
}

\begin{abstract}
This research is expected to become contribution for development of religious social science. Practically, this research is expected can present lessons learned for the partys (religious organization), for the agenda of activities advocate and empowering of society. This research is focused at organizational portrait and his religion figure activities. This research give information of profile organizations of religion in Salatiga, response and attitude to dynamics in multicultural society. This research done with collectively by different researcher, also differ academic background of him. Expected with the difference can enrich viewpoint in analysis and his study.

Technique of data collecting done/conducted with interview, observation and data collecting of related/relevant of religious organization, documents, photos, etc. Technique election of responder pursuant to social background, education, economic and also the understanding of religious experience for them. Responder also come from assumed expert informan understand with situation, and issue of problem regional. Data analysis conducted with descriptive method. Religious organizational here cover: Mosque of Al Atiiq, Great Mosque of Darul Amal, Javanese Christian Church (Gereja Kristen Jawa) Salatiga, Gereja Pantekosta Isa Almasib Indonesia (GPIAI) Efata Salatiga, The Roman Catholic of Paroki St. Paulus Miki Salatiga, Parisada Hindu Dharma Indonesia (PHDI), PCNU, PD Muhammadiyah. Interreligious relationship in Salatiga will harmony if role of religion elite can give explanation and calmness theologyly and sociological paradigm to the people of each openly and by dialogue. But Interreligious relationship can become under performing if happened gave economic social, education, and local politic management do not in control well.
\end{abstract}

Keywords: religious organization, dynamics, barmony. 


\section{Abstrak}

Penelitian ini di tujukan untuk perkembangan ilmu sosial keagamaan. Secara praktis penelitian ini merujuk pada aktivitas pemberdayaan masyarakat dalam bidang sosial keagamaan dari lembaga keagamaan yang ada. Selain daripada itu penelitian ini menampilkan potret keberagaman organisasi keagamaan yang ada di salatiga. Penelitian ini merupakan hasil kerjasama dari sejumlab peneliti yang memiliki latar belakang akademik dengan harapan dapat memberikan sudut pandang analisis yang berbeda.

Teknik dalam pengumpulan data yang dilakukan adalab dengan interview, observasi, foto serta dokumen dari lembaga keagamaan yang ada. Demikian halnya dalam penggalian data dari para responden dipertimbangkan juga latar belakang pendidikan sosial ekonomi dan pemahaman tentang agama. Sedangkan untuk menganalisa data menerapkan metode deskriptif. Sedangkan lembaga yang menjadi tempat penelitian adalah Masjid Al Atiiq, Masjid Agung Darul Amal, Gereja Kristen Jawa, Gereja Pantaikosta Isa Almasib Indonesia (GPIAI) Efata salatiga, Gereja Katolik St. Paulus Miki Salatiga, Parisada Hindu Dharma Indonesia (PHDI), PCNU, PD Mubammadiyah. Dari penelitian ini dapat digambarkan babwa kebidupan antar umat beragama di Salatiga secar umum dapat berjalan dengan baik jika lembaga-lembaga yang ada dapat memberikan pemahaman yang benar tentang paradigm sosial keberagaman agama. Jika tidak terkontrol dengan baik maka akan memperburuk bubungan keberagamaan yang ada.

Kata Kunci:Lembaga keagamaan, dinamis, harmoni

\section{Latar Belakang Masalah}

INDONESIA merupakan negara berbasis masyarakat majemuk yang antara lain ditandai oleh beragam suku, ras, dan juga agama. Keragaman ini menjadi unik oleh karena di dalam perbedaan-perbedaannya juga ada kemampuan menjalin komitmen serta kesadaran hidup bersama. Dengan demikian keragaman bukan dilihat sebagai perbedaan (secara spasial), melainkan sebagai kekayaan secara kultural.

Kesadaran masyarakat atas kemajemukan inilah yang dalam kehidupan masyarakat mutakhir biasa dikenal dengan masyarakat berkesadaran plural. Satu ciri utama masyarakat berkesadaran plural 
adalah pengakuan atas keperbedaan, dan keperbedaan itu sesungguhnya sunatullah (kehendak Tuhan), merupakan sesuatu yang nyata dan tidak bisa dipungkiri. Sebaliknya, penolakan terhadap pluralisme justru akan menimbulkan ketegangan dan bahkan konflik, karena meniadakan sesuatu yang nyata juga merupakan pengingkaran terhadap sunatullab tersebut. Dan, pluralisme pada dasarnya tidak sekedar menghendaki pengakuan atas keperbedaan itu, melainkan juga penghormatan atas kenyataan adanya perbedaan.

Agama adalah faktor komplementer dalam sebuah sistem kebudayaan. Kehadirannya cukup lama dalam perkembangan perjalanan tradisi kemasyarakatan kita. Penting untuk dipahami bahwa sejarah agama-agama besar di Indonesia adalah agama pendatang yang berasal dari India, Tiongkok, Portugal, Arab, dan Belanda (http://id.wikipedia.org/wiki/Agama_di_Indonesia\# cite_note-indency-6, diakses tanggal 8 Juli 2011). Disadari maupun tidak kehadiran itu telah menjadi pendorong terwujudnya keanekaragaman keagamaan maupun kultur. Melakukan konversi terhadap kepercayaan baru bukan suatu proses yang mudah, karena jauh sebelum agama-agama itu datang, kepercayaan (agama) lokal telah lebih dahulu hidup sebagai sistem kepercayaan bagi masyarakat setempat. Hadirnya suatu sistem kepercayaan baru sudah pasti menimbulkan ketegangan-ketegangan di antara kelompok masyarakat. Tetapi keanekaragaman agama dan kultur yang terpelihara hingga saat ini juga sebuah bukti, bahwa ketegangan-ketegangan itu adalah bagian dari sebuah dinamika yang tanpa menghilangkan arti sejarah.

Yang lebih rumit dalam memahami realitas keagamaan adalah hadirnya agama dalam pengalaman-pengalaman "batin" dan "perasaan" pada setiap individu sebagai anggota masyarakat. Pengalaman batin dan rasa keagamaan adalah sebuah tindakan yang serba subyektif yang tidak lagi terukur oleh kekuatan nalar. Dalam perspektif yang lebih ekstrim, berkeyakinan dalam suatu agama adalah sebuah spekulasi batin. Rasa meyakini atau tidak meyakini akan Tuhan adalah sebuah spekulasi yang tidak mungkin bisa dibuktikan secara nalar ilmiah. Namun demikian bagi individu atau suatu kelompok masyarakat, sikap beriman kepada Tuhan dianggap lebih menguntungkan sebagai sebuah pilihan karena lebih menentramkan batin seseorang. 
Sikap batin ini lebih banyak ditemukan dalam kehidupan masyarakat berbasis tradisi seperti di Indonesia. Di kawasan ini agama merupakan bagian penting yang turut terlibat dalam banyak segi kehidupan. Luasnya cakupan kehidupan yang turut melibatkan aspek keagamaan menjadikan agama tumbuh dan berkembang bersama tradisi yang berlaku dalam masyarakatnya. Agama dan tradisi ibarat dua sisi mata uang yang tidak saling terpisahkan, namun tetap bisa dikenali perbedaan mendasar sifat dan karakter antara keduanya. Karenanya setiap individu dapat dengan mudah menampilkan performance keagamaannya ke ranah publik tanpa beban kebersinggungan dengan unsur publik yang lain.

Performance yang kurang lebih sama ini juga ditemukan dalam keseharian masyarakat di Kota Salatiga. Masyarakat di kota ini adalah prototipe masyarakat plural baik secara etnis, agama, maupun budaya. Selain suku Jawa dan Tionghoa yang lebih dominan, masyarakat Kota Salatiga terdiri dari berbagai latar belakang suku dan etnis, seperti Batak, Minang, Dayak, Bugis, Ambon, Papua, dsb. Beberapa tradisi berkembang di kota ini dengan latar belakang agama Islam, Kristen, Tri Dharma, dan Hindu. Keragaman ini tetap mempelihatkan proses saling interaksi yang sangat terbuka dan dinamis. Boleh jadi ini juga dipengaruhi oleh pengalaman di masa lalu, tatkala semangat pluralisme memang telah lama berkembang.

Nama Salatiga memiliki hubungan dengan nama tokoh agama Dewi Trisala atau Siddhadewi pada tahun 750 M. Nama Trisala kemudian diambil sebagai nama tempat, yang kemudian berubah menjadi Salatri dan Salatiga. Siddhadewi adalah tokoh penganut agama Budha aliran Jaina yang dikenal sangat dekat dengan tradisi Hindu (Baehaqi, 2002: 184). Diduga tradisi ini yang turut membentuk tipologi masyarakat Salatiga yang bisa menerima dan tidak fanatik terhadap kehadiran agama baru, yakni Islam dan Kristen, di kemudian hari.

Faktanya, kehidupan yang harmonis di tengah-tengah keragaman tradisi dan agama telah berlangsung sejak lama di Salatiga. Bukanlah hal baru kalau para ibu-ibu turut terlibat merawat jenazah yang berlainan agama; bukan hal baru bila anak-anak muslim terlibat aktif berkesenian barongsai selepas dari belajar di TPA (Taman Pendidikan Al Qur'an); juga tidak mengherankan kalau pemuda 
gereja turut pula membantu penggalangan dana sebuah pembagunan masjid. Kesemuanya berlangsung secara alamiah dan terjadi bukan sebagai sesuatu yang dipaksakan.

Suasana yang dinamis di Kota Salatiga juga ditunjukkan dengan hadirnya lembaga-lembaga keagamaan. Lembaga-lembaga tersebut telah mampu mengembangkan kapasitasnya, bukan saja di bidang keagamaan melainkan juga bergerak di bidang lain, terutama pelayanan publik di bidang pendidikan, bidang ekonomi, dan bidang pemberdayaan masyarakat lainnya. Sebagai salah satu ukuran dari bukti perkembangannya adalah adanya respons dari masyarakat yang turut serta mengambil manfaat dari peranan lembaga-lembaga tersebut.

Perkembangan ini tentu saja tetap dilihat sebagai bentuk relasi pragmatis antara lembaga keagamaan dengan publiknya. Relasi antara lembaga keagamaan dan masyarakat tidak lebih dari sekedar relasi yang bersifat transaksional dan profitable. Tetapi bagaimana sikap dan respons lembaga-lembaga keagamaan terhadap dinamika keberagamaan masyarakat yang multikultural? Persoalan inilah yang hendak dicari pemahamannya secara lebih mendalam melalui studi/ penelitian.

\section{Perumusan Masalah Penelitian dan Tujuan Penelitian:}

1) Masalah Penelitian : Potret Organisasi /Lembaga Keagamaan dan Respon terhadap Dinamika Kehidupan Keberagamaan di Salatiga

2) Rincian Masalah Penelitian (MP) dan Tujuan Penelitian (TP):

(1)a. Mengidentifikasi lembaga-lembaga atau organisasi keagamaan di Kota Salatiga

b. Mengidentifikasi kegiatan-kegiatan yang dilakukan oleh lembaga-lembaga atau organisasi keagamaan di Kota Salatiga.

(2) Mengidentifikasi rinci tentang dinamika kehidupan keberagamaan di Kota Salatiga.

a. Mengidentifikasi Sikap dan pandangan organisasi keagamaan terhadap keberagamaan di Salatiga, dan alasanalasannya. 
b. Mengidentifikasi pengalaman/peristiwa/kasus terkait dengan isu, upaya-upaya penyelesaiannya, dan alasan yang melatarbelakanginya

\section{Tinjauan Pustaka}

Penelitian Singgih Nugroho tahun 2010 berjudul Menakar Kembali Tolerasi dan Intoleransi Agama di Jawa Tengah menyebutkan bahwa dukungan terhadap toleransi masih dimiliki oleh sebagian besar kalangan pemuka dan umat beragama. Tapi acapkali situasi itu tertutupi oleh gerakan intoleransi yang datang dari konstelasi politik identitas di aras lebih tinggi. Keberadaan forum-forum dialog agama baik yang diinisiasi oleh pemerintah (daerah) maupun masyarakat sipil yang ada diberbagai daerah Jawa Tengah seharusnya merupakan modal penting untuk mengelola potensi negatif dari kemajemukan agama. Penting juga organisasi masyarakat sipil bekerjasama secara kritis dengan aparat pemerintah mengawal proses pendewasaan beragama mereka dan masyarakat luas. Dengan cara ini diharapkan praktek kekerasan keagamaan ke depan akan terminimalisir. Jika penelitian Singgih lebih berfokus pada upaya menggali potensi kerjasama dan mendata akar masalah peluang konflik yang ada dalam dinamika agama di Jawa Tengah, sementara penelitian ini lebih berfokus pada sikap dan pandangan para tokoh agamawan dalam dinamika keagamaan di Salatiga dan bagaimana upaya penyelesaiannya dari kasus-kasus yang ada. Penelitian ini juga diarahkan lebih spesifik dalam kawasan teritorial yang terbatas yakni Kota Salatiga, dan isu-isu lokalitas keagamaan.

Sementara itu penelitian M. Zulfa berjudul Ziarah Spritual Mewujudkan Kerukunan dan Toleransi Beragama: Studi Fungsional Pendidikan Agama Pada Beberapa SMA di Salatiga tabun 2010 lebih menfokuskan isu-isu dan kerja-kerja kerukunan dan penghayatan keagamaan pada wilayah tenaga pendidikan di lingkungan SMA di Salatiga. Dalam penelitian tersebut ditemukan bahwa para guru di satuan pendidikan setingkat SMA tidak memberikan pengetahuan seputar isu dan pengetahuan perbadingan agama, namun lebih menekankan aspek kerukunan umat beragama. Lebih jauh penelitian tersebut menyebutkan bahwa para guru umumnya menganjurkan kerukunan umat beragama namun belum secara 
komprehensif mengkaitkan isu kerukunan umat beragama dengan nilai-nilai universalisme dalam agama-agama sehingga ruang dialog belum terbuka dan terejawantahkan secara optimal. Jika penelitian M. Zulfa lebih terfokus pada penghayatan keagamaan dan kerukunan agama pada para guru, maka penelitian ini lebih terfokus pada tokoh-tokoh agama serta mencari dan mengetahui pandangan para tokoh agama menyangkut dinamika, kasus, sikap serta sikap keberagamaannya. Lebih jauh penelitian ini juga akan mengidentifikasi pengalaman/peristiwa/kasus terkait dengan isu, upayaupaya penyelesaiannya, dan alasan yang melatarbelakanginya.

Sementara itu hasil penelitian yang diterbitkan oleh Badan Litbang Kementerian Agama RI., Pola Interaksi Antar Umat Beragama Di Kotesan, Prambanan, Klaten, 2006, menunjukkan bahwa interaksi antar umat beragama di Kotesan, Prambanan, Klaten merupakan warisan sejarah yang telah diturunkan dan dilestarikan dari generasi ke generasi. Terbentuknya relasi ini dipengaruhi oleh beberapa kondisi antara lain kondisi geografis, sistem sosial, sistem mata pencaharian, kondisi perekonomian masyarakat, dan tingkat kesejahteraan yang relatif seimbang. Disamping itu, ternyata semua pihak seperti aparat desa, tokoh masyarakat, tokoh agama, dan anggota masyarakat terlibat secara aktif bahu-membahu untuk senantiasa membangun, memperkuat, serta melestarikan interaksi yang telah terbangun bersama-sama. Terdapat dua faktor utama yang mempengaruhi terbangunnya interaksi antar umat beragama di Kotesan yakni faktor internal dan faktor eksternal. Faktor-faktor internal yang mempengaruhi interaksi antar umat beragama di Kotesan antara lain ikatan emosional, ikatan budaya, ikatan kekeluargaan, dan faktor ajaran agama. Sedang faktor-faktor eksternal terdiri dari kontak dengan masyarakat luar serta mobilitas masyarakat. Masyarakat Kotesan melestarikan interaksi antar umat beragama tersebut melalui berbagai cara antara lain melalui kegiatan sosial, dialog, pembinaan pemerintah setempat, dan pembinaan keagamaan secara internal. Kegiatan sosial merupakan wahana yang paling dominan karena melalui kegiatan informal itu cakupan peserta dan bidang yang dibicarakan jauh lebih luas. Hal ini tidak akan diketemukan di dalam dialog, pembinaan pemerintah, dan pembinaan keagamaan secara internal. Dalam kegiatan sosial 
tersebut misalnya pertama: semua masyarakat terlibat, dan ini tentu sulit terpenuhi dalam dialog, pembinaan oleh pemerintah setempat, dan terlebih-lebih dalam pembinaan internal agama. Kedua, tidak ada sekat agama, mungkin situasi ini dapat terkondisikan dalam dialog dan pembinaan pemerintah setempat, tetapi sulit terpenuhi dalam pembinaan internal agama.

Jika penelitian terdahulu lebih menitikberatkan hubungan antaragama, dimensi sosial agama para aras lokal, serta pola interaksi antarumat beragama, maka penelitian ini lebih fokus pada potret organisasi dan aktifitas para tokoh agamanya. Disamping penelitian ini juga berhasil memberikan informasi atau profile kelembagaan agama di Salatiga, penelitian ini dikerjaan secara kolektif oleh para peneliti yang berbeda agama kepercayaannya, juga berbeda latarbelakang akademisnya. Diharapkan dengan perbedaan tersebut dapat memperkaya sudut pandang dalam analisis dan telaahnya.

\section{Kerangka Teori}

Penelitian ini menggunakan kerangka teori yang dikemukakan oleh Mukti Ali. Menurut Mukti Ali (Mulyanto Sumardi, 1982: 20-30), masyarakat Indonesia adalah masyarakat yang bercorak agamaniah (religius). Mempelajari masyarakat Indonesia tidak bisa tidak harus pula membicarakan agama yang dipeluk warga masyarakat Indonesia. Jadi menstudi kehidupan masyarakat yang makin lengkap adalah bila juga mengungkapkan dorongan-dorongan apa yang menimbulkan tingkah-lakunya, yaitu antara lain ungkapan-ungkapan batin berupa keyakinan-keyakinan yang dibentuk oleh agama yang dianut orang-orang/warga masyarakat. Agama selain membentuk keyakinan yang dianut juga mengarahkan tingkah laku interaksi sosial (pergaulan sesama manusia). Jadi, agama mengandung segi keyakinan dan segi interaksi sosial.

Selanjutnya Mukti Ali menyatakan bahwa agama sebagai refleksi iman mencakup baik kepercayaan maupun pengungkapan kepercayaan agama itu dalam dunia (ungkapan dan refleksi dogmatis). Agama mencakup iman dan ungkapan iman dalam perbuatan nyata. Refleksi iman/refleksi agamaniah adalah penghayatan tentang ajaran agama, sedangkan refleksi terhadap ajaran agama 
adalah bagaimana manifestasi iman dalam kehidupan bersama masyarakat (sesama umat dengan yang lain). Hidup keagamaan itu bukanlah hidup batin saja, bukan hidup pribadi saja; hidup keagamaan berpangkal pada kepercayaan kepada agama (iman) yang diyakini dan bagaimana menerapkan keyakinan itu dalam kehidupan masyarakat "sesuai" dengan keyakinan batin itu.

Sementara Mattulada (Mulyanto Sumardi, 1982: 50-69) mengemukakan bahwa hidup keagamaan adalah suatu fenomena kehidupan dalam masyarakat dan kebudayaan yang tidak terlepas dari segi-segi kehidupan lainnya, sebagai pernyataan keutuhan hidup. Agama adalah realitas/gejala yang terjadi secara lain daripada kenyataan-kenyataan bukan agama (yang biasa), karena melibatkan hal-hal di luar jangkauan penalaran (logika) semata-mata.

Dalam sifatnya yang abstrak, "religion expands the visiblr $\backslash$ e in order to endow it with the force of nonvisible realities". Realitas yang nonvisible dapat ditempatkan "di tempat yang tinggi" dan terdiri dari Allah yang Esa, dewa-dewa, roh-roh. Realitas yang nonvisible itu dapat ditempatkan " di masa lampau secara horizontal" dan terdiri dari tradisi-tradisi sacral lama, pihak-pihak lain yang penting berikut pengalaman-pengalamannya (misalnya para leluhur) yang tidak lagi hadir secara fisik namun dapat diundang untuk berpartisipasi dalam situasi kini, atau dapat berupa suatu Masa Keemasan di waktu lampau yang direpresentasikan sebagai suatu ukuran untuk menilai realitas masa kini. Realitas nonvisible itu sebaliknya dapat ditempatkan "di depan secara horizontal" sebagai citra mengenai suatu surga baru/suatu dunia baru yang dimunculkan agar menjadikan masa kini berperan dalam gerakan yang bermakna menuju suatu masa depan yang lebih baik. Perluasan (ekspansi) dari realitas masa kini mungkin pula dicari ke kedalaman, yaitu ke dalam kedalaman jiwa seseorang lalu menjadi suatu proses batiniah yang lebih bercorak mistik.

Bagaimanapun, dalam hal-hal tersebut itu, agama memberi "inspirasi", yaitu: orientasi (bila harus membuat pilihan/keputusan), legitimasi (tatkala pilihan/keputusan dibuat), dan pemberdayaan (untuk menerapkan keputusan yang dibuat). "Realitas yang diperluas" ini tidak dapat diperhitungkan secara matematis atau diuji 
secara empiris. Realitas itu irrasional (meskipun bukanlah antirasional).

Agama selalu bisa mengalami resiko-resiko bahwa realitas yang diperluas itu tidak hanya merembes ke masa kini tetapi bahwa ia dapat mengakibatkan masa kini nyaris lenyap. Masa kini dapat ditekan oleh realitas yang diperluas itu. Orang-orang, misalnya, dapat menarik diri mereka ke dalam apa yang bagi pihak luar dipandang sebagai suatu dunia fantasi. Atau mereka bertindak seolah-olah relaitas yang diperluas itu merupakan satu-satunya hal yang penting dan menjadi orang-orang fanatik atau bahkan melakukan kekerasan. Demikianlah, religi/agama memilii resiko inheren yang mengakibatkan orang-orang kurang memperhatikan situasi spesifik yang dialaminya.

\section{Metode Penelitian}

a. Metode dan Teknik Pengumpulan Data

(1) Metode: Deskriptif purposif sampling yang aras sasaran penelitiannya sebagai berikut: Satuan Analisis (SA), Satuan Pengamatan (SP), Sumber Informasi (SI).

SA dan SP : meliputi lembaga-lembaga organisasi keagamaan di Salatiga

\begin{tabular}{|c|c|c|c|c|c|c|}
\hline \multirow{2}{*}{ No. } & \multirow{2}{*}{$\mathbf{S A}$} & \multirow{2}{*}{ SP } & \multicolumn{3}{|c|}{ SI } & \multirow{2}{*}{$\Sigma$} \\
\hline & & & & Kategori & & \\
\hline \multirow{2}{*}{1.} & \multirow{2}{*}{ Masjid } & & \multirow{2}{*}{$\begin{array}{l}\text { Ta'mir } \\
\text { Masjid }\end{array}$} & (Raya) & $\begin{array}{ll}- & \text { Imam } \\
- & \text { Ketua ta'mir } \\
- & \text { Jama'ah }\end{array}$ & 3 \\
\hline & & & & (Jami') & $\begin{array}{ll}\text { - } & \text { Imam } \\
\text { - } & \text { Ketua ta'mir } \\
\text { - } & \text { Jama'ah } \\
\end{array}$ & 3 \\
\hline \multirow{3}{*}{2.} & \multirow{3}{*}{$\begin{array}{c}\text { Gereja } \\
\text { Kristen }\end{array}$} & & \multirow{3}{*}{$\begin{array}{l}\text { Majelis } \\
\text { Gereja / } \\
\text { organisasi } \\
\text { gereja }\end{array}$} & GKJ & $\begin{array}{ll}\text { - } & \text { Ketua } \\
& \text { Majelis } \\
\text { - } & \text { Pendeta } \\
\text { - } & \text { Jemaat } \\
\end{array}$ & 3 \\
\hline & & & & GKJ TU & $\begin{array}{ll}\text { - } & \text { Ketua } \\
& \text { Majelis } \\
\text { - } & \text { Pendeta } \\
\text { - } & \text { Jemaat } \\
\end{array}$ & 3 \\
\hline & & & & Pantekosta & $\begin{array}{ll}\text { - } & \text { Gembala } \\
\text { - } & \text { Pendeta } \\
\text { - } & \text { jemaat } \\
\end{array}$ & 3 \\
\hline
\end{tabular}




\begin{tabular}{|c|c|c|c|c|}
\hline 3. & $\begin{array}{c}\text { Gereja } \\
\text { Katholik }\end{array}$ & $\begin{array}{l}\text { Dewan } \\
\text { paroki }\end{array}$ & $\begin{array}{ll}\text { - } & \text { Ketua harian } \\
\text { - } & \text { Anggota } \\
\text { - } & \text { Umat (2) } \\
\end{array}$ & 4 \\
\hline 4. & Hindu & $\begin{array}{l}\text { Pengurus } \\
\text { organisasi }\end{array}$ & $\begin{array}{ll}- & \text { Ketua } \\
- & \text { Anggota } \\
- & \text { Umat }(2) \\
\end{array}$ & 4 \\
\hline 5. & \multirow{3}{*}{$\begin{array}{l}\text { Organisasi } \\
\text { keagamaan }\end{array}$} & $\begin{array}{l}\text { Nahdlatul } \\
\text { Ulama }\end{array}$ & $\begin{array}{ll}- & \text { Ketua } \\
\text { - } & \text { Anggota } \\
\text { - } & \text { Kader } \\
& \text { organisasi } \\
\end{array}$ & 3 \\
\hline 6. & & Muhammadiyah & $\begin{array}{ll}\text { - } & \text { Ketua } \\
\text { - } & \text { Anggota } \\
\text { - } & \text { Kader } \\
& \text { organisasi }\end{array}$ & 3 \\
\hline & & $\sum$ & & 29 \\
\hline
\end{tabular}

Lokasi Penelitian: Wilayah Kota Salatiga serta waktu penelitian dimulai pada Januari hingga September 2011

(2) Teknik Pengumpulan Data: dilakukan dengan wawancara untuk MP/TP 1 \& 2, melakukan observasi untuk MP/TP 2 dan pengumpulan data sekunder untuk MP/TP 1 (Terkait organisasi keagamaan, dokumen, foto, dsb.)

b. Tenaga peneliti berasal dari STAIN Salatiga, Lembaga Percik, perwakilan GKJ TU, dan PHDI yang terdiri dari : 1. Benny Ridwan, 2. Daniel, 3. Mohammad Akbar, 4. Adang Kuswaya, 5. Agung Waskitoadi, 6. Ambar Istiyani, 7. Endang dan 8. Mangku Bibit.

\section{Pembahasan}

Identifikasi kegiatan organisasi sosial keagamaan yang ada di Salatiga seperti PCNU, PD Muhammadiyah dan PHDI (Parisada Hindu Dharma Indonesia), dengan mengusung visi dan misinya masingmasing hadir menjaga harmoni hubungan antaragama dan memiliki dinamika secara internal dan eksternal. Tiap organisasi menawarkan berbagai bentuk perubahan dan pembaruan menurut versi dan visinya masing-masing. Pada umumnya, organisasi sosial keagamaan terbentuk karena adanya keinginan yang kuat dalam suatu kelompok untuk menyesuaikan diri (beradaptasi) dengan format kehidupan yang baru seiring dengan perkembangan ilmu pengetahuan dan teknologi. Bersamaan dengan itu, muncullah berbagai pemikiran-pemikiran baru, yang kemudian menjadi landasan dalam 
kehidupan organisasi tersebut. Dari pemikiran-pemikiran baru inilah, kemudian berkembang suatu gaya hidup dan ideologi baru di komunitas-komunitas masyarakat tertentu, yang kemudian disebut sebagai hasil pemikiran modern. Intinya, suatu pemikiran baru dalam kehidupan beragama tidak akan terealisasi tanpa adanya organisasi keagamaan yang mendukung pemikiran tersebut, serta organisasi keagamaan pun tidak akan terbentuk tanpa adanya pemikiranpemikiran baru, dan apabila demikian, maka kehidupan masyarakat agama tidak akan mampu bertahan dalam kompetisi kehidupan beragama di masyarakat. Karena, untuk menjadi kuat, umat harus bersatu dan terus berusaha beradaptasi dengan perubahan-perubahan yang terjadi di dunia sekitarnya. Di Salatiga, telah lahir dan berkembang banyak organisasi sosial keagamaan yang berperan besar dalam pembaruan kehidupan masyarakat agamaniah. Organisasi seperti NU, Muhammadiyah dan PHDI pada titik yang sama memiliki jaringan horizontal dan vertikal sampai ke tingkat pusat dan menyebar di seluruh Indonesia.

Sementera itu masjid sebagai suatu kelembagaan agama merepresentasikan suatu karakter ketundukan total (sujud) kepada Allah SWT, sehingga ia dapat secara mudah (karena ketundukannya yang total itu) memberi makna hidup dan kehidupan melewati batas-batas ruang dan waktu; semangatnya adalah tunduk, taat dan patuh. Jika masjid Al Atiiq memiliki sejarah yang cukup panjang dan memiliki makna kemerdekaan agar umat yang beribadah di masjid Al-Atiiq juga merasakan kedamaian dan kemerdekaan, maka masjid raya Darul Amal yang berada di lingkungan dan disekitar areal lembaga pendidikan tinggi sebagian besar jemaahnya adalah warga lembaga pendidikan tinggi tersebut (civitas academica). Dengan posisi fisiknya yang berada di sekitar dan areal kampus, maka dapat dipastikan bahwa jemaahnya akan sangat dinamis, senantiasa mempunyai kesempatan untuk memperbarui semangat dan komitmennya kepada idealismenya. Masjid ini akan selalu mempunyai jemaah angkatan muda dalam porsi cukup besar dan relatif konstan jumlahnya, karena yang pergi akan senantiasa tergantikan. Yang pergi akan membawa nilai-nilai baru dalam generasinya, yang diperoleh melalui masjid kampus, yang akan mewarnai perjalanan hidup selanjutnya di masyarakat. Yang datang 
akan membawa semangat mudanya, yang haus akan perubahan menuju ke yang lebih baik, yang lebih sarat muatan pengetahuan dibanding generasi sebelumnya. Juga, masjid ini mempunyai akses yang baik pada informasi dan sumber daya manusia dengan berbagai kepakaran yang relevan dengan kebutuhan untuk pembentukan, pembinaan dan pengembangan sumber daya manusia unggul masa depan.

Kombinasi semangat ketundukan, ketaatan kepada Allah SWT dengan sikap kritis terhadap kemapanan yang tidak lagi relevan dengan perkembangan zaman merupakan modal yang amat berharga untuk membangun suatu pusat unggulan, suatu pusat yang senantiasa berorientasi pada kualitas. Selain menyediakan tempat shalat, masjid juga menjadi inspirator bagi gerakan sosial intelektual, kajian politik, dan apresiasi kebudayaan. Pada riset ini ditemukan adanya beberapa program pemberdayaan yang dapat dikembangkan. Mulai dari pengelolaan Lembaga Amil zakat dan pelaksanaan qurban, pengelolaan TPA-TPQ, remaja masjid sampai pada upaya kemandirian koperasi masjid dan perpustakaan masjid.

Sementara itu kegiatan-kegiatan gereja sebagai pusat peribadatan namun disisi lain gereja juga sangat konsen terhadap pemeliharaan nilai-nilai lokal. Pemuka-pemuka Gereja tidaklah sulit mempertemukan tradisi dengan liturgi gereja. Sebagaimana yang dilakukan Gereja Kristen Jawa (GKJ) Sidomukti dengan Batik sidomuktinya. Pada sisi lain Gereja Pantekosta Isa Almasih Indonesia (GPIAI) EFATA konsern dan memiliki lembaga pendidikan tinggi Sekolah Tinggi Teologi (STT) EFATA. Berdirinya lembaga pendidikan ini didasarkan oleh kebutuhan gereja untuk membangun kaderkader penerus di GPIAI yang akan menjalankan tugas-tugas penggembalaan, pemuridan, pengutusan, penginjilan dan pembangunan jemaat secara berkelanjutan. Saat ini STT telah memiliki dua program jurusan pendidikan, yakni program jurusan Pendidikan Agama Kristen (PAK) dan program jurusan Teologi. Jika GKJ Sidomukti konsen terhadap pemeliharaan nilai-nilai lokal, GPIAI konsen dan memiliki lembaga pendidikan tinggi Sekolah Tinggi Teologi (STT) EFATA, maka Gereja Katolik Santo (St.) Paulus Miki Salatiga lebih memperhatikan kaum KMLTD (Kaum Miskin, Lemah, Tersingkir, dan Defable). untuk perhatian terhadap KMLTD, telah ada kegiatan 
APP (Aksi Puasa Pembangunan) yang kegiatanyan dilakukan sebelum Paskah. Setiap Lingkungan akan mendata KMLTD. Data tersebut kemudian juga diberikan kepada Paroki. Setiap pertemuan akan ada kolekte (mengumpulkan rejeki) yang dilakukan per Lingkungan. Hasil kolekte tersebut diarahkan kepada KMLTD di masingmasing Lingkungan dan sebagian disetorkan ke Paroki kemudian Paroki menyerahkannya kepada orang yang membutuhkan.

\section{Dinamika Organisasi Keagamaan Terhadap Keberagamaan Di Salatiga}

Mengenai sikap dan pandangan lembaga terhadap kehidupan keberagamaan di Salatiga, "Pada dasarnya Lembaga Masjid Jami "AL-ATIIQ" Kauman Salatiga, Takmir Masjid Raya Darul Amal sangat menghormati keberagaman dan toleransi terhadap kehidupan keberagamaan di Salatiga", sebagaimana ditegaskan oleh Drs. H. Syatibi, Imam dan Nadzir Masjid Jami "AL-ATIIQ" dan Prof Muh. Zuhri. Hal yang senada juga diungkapkan oleh Qoribullah Budi Santosa, Ketua Majlis Ta'mir Masjid Jami "AL-ATIIQ" Kauman Salatiga, walau sebenarnya "lebih bersifat pandangan pribadi, semoga juga menjadi pandangan lembaga, bahwa terhadap kehidupan keberagamaan di Salatiga lebih mengedepankan kerukunan dan kebersamaan. Karena Salatiga ini sudah sejak jaman dulu sangat dikenal kerukunannya. Namun demikian, peranan tokoh agama memang menjadi sangat sentral untuk turut memecahkan masalah-masalah umat melalui siraman rohani. Dalam kaitan dengan itu, Yahya selaku takmir Masjid Raya Darul Amal sangat menekankan perlunya setiap pemimpin agama/pendakwah yang pertama- tama memperbaiki keimanan para pemeluknya masing-masing. Berdakwah sebaiknya tidak mencari kuantitas atau mencari jumlah pemeluk yang banyak, akan tetapi berdakwah lebih berorientasi pada kualitas para umat dalam hal pengetahuan dan pengamalan ajaran agama. Berikutnya juga agar tidak berdakwah kepada masyarakat yang sudah memeluk agama,karena bila para pendakwah mendakwahkan agamanya pada satu tujuan maka hal ini akan bertemu diantara pendakwah sehingga kemungkinan besar akan terjadi persaingan yang tidak sehat

Sikap dan pandangan para pemuka agama pada Masjid Al Atiiq dan Darul Amal merupakan bentuk upaya dialogis antar iman 
dalam membangun hubungan yang saling menguatkan dan menjaga. Sikap dan pandangan yang terbuka terhadap golongan beragama lain ini didasarkan pada keteladanan Nabi Muhammad semasa hidupnya. Keterlibatan pemuka agama-agama tersebut di dalam masyarakat memiliki andil yang cukup penting dalam penyelesaian masalah yang ada di masyarakatnya. Wadah seperti Majelis Puasa (Pimpinan Umat Beragama Salatiga) dan FKUB (Forum Kerukunan Umat Beragama) dipandang efektif untuk memberi ruang dialog dan bertukar informasi mengenai perkembangan dan dinamika antaragama. Hubungan baik antarpersonal pemuka agama harus juga mewarnai hubungan baik antarlembaga keagamaan di Salatiga.

Keragaman keagamaan masyarakat di Salatiga dipandang oleh GKJ (Gereja Kristen Jawa) sebagai sebuah realita. Hal itu tidak bisa dihindari, memandang perbedaan yang ada secara etis moral, ujar pendeta Pdt. Eben. Bahkan isu-isu mengenai pluralisme pun tidak luput dari materi diskusi jemaat GKJ Sidomukti, mengingat kondisi masyarakat Salatiga itu sendiri yang majemuk. Etis moral dalam memandang perbedaan yang dipegang oleh GKJ mengaju pada aspek kemanusiaan yang merupakan bagian dari teologi sosial. Dalam rangka menyongsong kemajemukan tersebut, GKJ juga mengakomodasi pemberkatan pernikahan beda agama. Hal ini berdasar dari tafsiran GKJ sendiri, salah satunya yang bersumber dari Korintus (jemaat plural). Pemberkatan dianggap tidak sama dengan sakramen. Pemberkatan adalah memohon berkat dari Tuhan (Allah), dan siapapun bisa memohon berkat itu, tanpa terkecuali. Meskipun tidak dipungkiri bahwa pro dan kontra masih saja terjadi hingga saat ini, bahkan dalam tubuh Majelis GKJ itu sendiri, demikian imbuhnya

Dari sudut pandang Gereja Pantekosta Isa Almasih Indonesia (GPIAI) melalui Pdt. Surya, melihat fenomena keragaman keagamaan di Salatiga bukan hal baru. Hal ini juga dibuktikan dari pengalaman Pdt. Surya yang selama 14 tahun memegang jabatan Ketua Umum Gereja-geraja di Salatiga. Dari awal GPIAI memang menginginkan adanya komunikasi dan menjadi jembatan antara pemerintah dengan gereja-gereja, juga antara gereja dengan seluruh komunitas secara lintas-agama di Salatiga sehingga dengan demikian 
dengan komunikasi ini dapat terjalin hubungan dan kerjasama untuk kepentingan-kepentingan kemanusiaan. Selanjutnya adalah menekankan pentingnya komunikasi secara terbuka dan berimbang untuk menyelesaikan masalah dinamika eksternal keagamaan. Kasus kehadiran jemaat Saksi Yehova dan kegiatan ibadah oleh komunitas Gereja Metodist di sebuah kawasan pemukiman di Dukuh Bancaan dapat diselesaikan oleh komunikasi yang terbuka dan berimbang ini dengan difasilitasi oleh pemuka agama.

Hal lain yang juga perlu disimpulkan adalah ketika Gereja Katolik Paroki St. Paulus Miki Salatiga terbuka dan memandang sebuah pluralitas. Gereja berpendapat bahwa permainan liong tidak berkaitan dengan iman, melainkan tradisi atau kekayaan budaya yang perlu dikembangkan. Setelah Kong Hu Chu menjadi agama resmi negara atas jasa Presiden Abdurrahman Wahid, ada sebagian umat Katolik terutama yang etnis Cina selain pergi ke Gereja juga ke Klenteng. Gereja juga menyadari bahwa ada dua tujuan orang pergi ke Klenteng yaitu untuk menjalankan ritual agama atau untuk menjalankan tradisi etnis Cina. Belum diketahui secara persis tujuan sebagian umat Katolik ini pergi ke Klenteng. Hal ini belum diangkat sebagai masalah Gereja karena tidak berpengaruh kepada Gereja. Bahkan di SMP Katolik Stella Matutina ada ekstra kurikuler liong (barongsai), padahal liong bukanlah tradisi Katolik. Anak-anak yang bermain liong, bukan hanya anak-anak dari Buddha atau Kong $\mathrm{Hu} \mathrm{Chu}$, tetapi juga anak-anak Katolik yang pergi ke Gereja. Keterbukaan gereja dalam memandang tradisi patut diberi apresiasi yang bagus. Dalam hal agama dengan budaya lokal, Gereja Katolik memang sangat terbuka dengan budaya. Dicontohkan oleh seorang sumber informasi, dalam kematian ada peringatan tiga hari, tujuh hari, empat puluh hari dan seterusnya. Budaya yang sebetulnya dari Jawa ini kemudian dibungkus dengan iman Katolik. Umat Katolik juga memperingatinya karena angka-angka tersebut adalah angka yang bermakna bagi Katolik, yaitu: Dulu Yesus berpuasa selama empat puluh hari; Bangsa Israel memasuki Tanah Terjanji setelah empat puluh tahun; Tuhan menciptakan dunia selama tujuh hari; Yesus mengampuni tujuh puluh tujuh kali.

Sementara itu dalam persoalan tanah Salib Putih ini PCNU (Pengurus Cabang Nahdlatul Ulama) berpandangan bahwa 
sebaiknya pemerintah kota Salatiga bisa mengambil kebijakan yang tepat untuk menjaga kondisi kondusif di Salatiga seperti memberikan kapada kelompok Islam tersebut tanah lain misalnya bengkok, agar mereka juga juga diakomodasi kebutuhannya. Pengambilan kebijakan ini perlu agar tidak terlalu terlihat adanya kelompok yang diistimewakan. Sedangkan untuk memecah tanah Salib Putih itu tidak mudah karena ada sejarah, dan sejarah perlu juga dijaga.

Begitu juga dengan kehidupan beragama, semua umat saling menjaga sikap yang sekiranya tidak baik dan membuat orang lain tidak suka. Acuan yang dipegang oleh Parisada Hindu Dharma Indonesia (PHDI) berkaitan dengan realitas hubungan antar agama yaitu tetap menjaga adanya kerukunan antar umat beragama sehingga semua yang hidup bisa hidup lebih rukun. Sebagai contoh bahwa umat mempunyai pedoman yang selalu dipegang "saya adalah anda" mempunyai makna bahwa jika kita menghormati orang lain berarti kita juga menghormati diri kita sendiri tetapi jika kita tidak menghormati orang lain maka kita tidak menghormati diri kita sendiri. Intinya peranan PHDI senantiasa berusaha membangun dan menjaga hubungan yang harmonis dan keserasian hidup antar umat beragama serta alam semesta. Ketika ditanya mengapa? Pak Putu (Sekretaris PHDI Kota Salatiga) menjawab bahwa jelas sekali hal tersebut apa yang tertulis di dalam kitab suci Veda, dan saya yakin dalam kitab suci agama apapun menyatakan bahwa perbedaan bukan alasan untuk tidak hidup secara damai, dan selalu hormat-menghormati.

Muhammadiyah mengakui realitas keragaman keberagamaan dan budaya sebagai sebuah sunnatullah sesuatu diyakini sebagai suatu keniscayaan. Sunatullah adalah hukum alam, misalnya lahir dan mati. Dalam Islam terdapat hukum alam yang pasti misalnya matahari terbit dari timur, api membakar.Keberagaman tersebut dapat hidup eksis berdampingan secara damai dan tumbuh kembang di bumi Indonesia dengan acuan sumber primer ajaran Islam dan UUD '45. Peran yang dilakukan adalah selalu menampilkan gerakan Islam yang moderat, tidak memperlihatkan watak ekslusivitas yang mengarah pada sikap menegasikan kelompok yang berbeda, apalagi meremehkan orang lain. Kaitannya adalah multikutlural harus dipelihara sebagai aset dan diberi peluang untuk 
berkembang. Terkait dengan relitas hubungan antar agama Imam Sutomo (Ketua Pimpinan daerah Muhammadiyah Salatiga) menyatakan bahwa masyarakat Indonesia masih dalam proses demokrasi. Hubungan antaragama di Indonesia termasuk masalah sensistif, dan dapat mengarah pada konflik jika tidak disikapi secara santun. Dikotomi masyoritas vs minoritas masih menjadi alat untuk menghakimi pihak lain. Mayoritas sering dipojokkan sebagai tidak toleran, sedangkan minoritas selalu mengedepankan kebebasan dan hak asasi. Muhammadiyah memposisikan sikap aktif dalam mempropagandakan Islam kepada warga Muhammadiyah sebagai agama yang cinta damai, agama yang moderat, agama yang selalu menjunjung tinggi nilai-nilai kemanusiaan. Peran Muhammadiyah dalam dakwah selalu mengedepankan Islam sebagai agama penuh rahmat, agama pembawa kedamaian. Muhammadiyah mengajak warganya bersikap moderat, belajar hidup berdemokrasi dalam masyarakat plural. Semangat yang mendasarinya bahwa kehadiran Islam harus dapat menjadi contoh untuk menegakkan kebenaran, kejujuran, kebersamaan, dan kedamaian.

Berikut ditampilkan macam organisasi/lembaga keagamaan, karakteristik pemahaman dan pandangan para aktor yang mewakili organisasi tersebut (walaupun tidak serta merta mewakili pandangan organisasi), cita-cita dan harapan ke depan dalam menjaga kondusifitas hubungan antaragama dan memelihara hubungan antaragama serta background aktifitas mereka (tabel 1). Pada tabel 2 dapat digambarkan identifikasi problem dan dinamika yang dihadapi oleh organisasi/lembaga keagamaan dalam lingkup penelitian ini.

\section{Tabel 1}

\begin{tabular}{llll}
\hline \multicolumn{1}{l}{ Organisasi } & \multicolumn{1}{c}{ Karakteristik } & Cita-cita & Aktor \\
\hline 1. Masjid AL-ATIIQ & 1. Menerima pluralitas & 1. Perdamaian & 1. Akademisi \\
2. Masjid Raya Darul Amal & sebagai kenyataan & 2. Saling hormat & 2. Agamawan \\
$\begin{array}{l}\text { 3. GKJ Salatiga } \\
\text { 4. Gereja Pantekosta Isa }\end{array}$ & 2. Kritis atas teks dan & menghormati & 3. Polisi \\
Almasih Indonesia & suci agama-agama & 3. Pusat unggulan & 4. Guru \\
(GPIAI) Efata Salatiga & 3. Menerima & 5. Mencerdasakan & 6. Mahasiswa \\
5. Gereja Katolik Paroki St. & modernisasi dan & masyarakat dan & 7. Karyawan \\
Paulus Miki Salatiga & menjaga budaya & menjaga stabilitas & 8. Ibu Rumah tangga \\
6. PHDI & lokal & keamanan & 9. wiraswasta \\
7. NU & 4. Kontekstual dalam & 6. multikutlural harus & \\
8. Muhammadiyah & memahami teks & dipelihara sebagai & \\
& agama & aset dan diberi & \\
& & peluang untuk & \\
\end{tabular}




\section{Tabel 2}

\begin{tabular}{|c|c|}
\hline Lembaga/Organisasi Keagamaan & Identifikasi Problem dan Dinamika \\
\hline 1. Masjid AL-ATIIQ & $\begin{array}{l}\text { Pemuda dari Indonesia Timur vs pemuda lokal } \\
\text { di Kauman, Miras di kawasan Jetis, persoalan } \\
\text { suami-istri yang sering bertengkar, } \\
\text { perselingkuhan, nikah siri yang tidak jadi } \\
\text { menikah. Pemilukada dan politik uang. }\end{array}$ \\
\hline 2. Masjid Raya Darul Amal & $\begin{array}{l}\text { NII dan dangkalnya pemahaman Jihad, tidak } \\
\text { kritis terhadap teks dan penafsiran ajaran } \\
\text { agama }\end{array}$ \\
\hline 3. GKJ Salatiga & $\begin{array}{l}\text { Perkawinan beda agama, Perayaan Idul Fitri } \\
\text { yang bersamaan dengan Hari Minggu } \\
\text { hubungannya dengan isu mengancam warga } \\
\text { gereja }\end{array}$ \\
\hline $\begin{array}{l}\text { 4. Gereja Pantekosta Isa Almasih } \\
\text { Indonesia (GPIAI) Efata Salatiga }\end{array}$ & $\begin{array}{l}\text { Saksi Yehova dan kegiatan ibadah oleh } \\
\text { komunitas Gereja Metodist }\end{array}$ \\
\hline $\begin{array}{l}\text { 5. Gereja Katolik Paroki St. Paulus } \\
\text { Miki Salatiga }\end{array}$ & $\begin{array}{l}\text { Sebagian umat Katolik terutama yang etnis Cina } \\
\text { selain pergi ke Gereja juga ke Klenteng, } \\
\text { Perhatian (masalah biaya) aparat kepolisian saat } \\
\text { menjaga Gereja (diminta atau proaktif) }\end{array}$ \\
\hline 6. PHDI & $\begin{array}{l}\text { Permohonan tanah/lokasi untuk awal pendirian } \\
\text { Pura }\end{array}$ \\
\hline 7. $\mathrm{NU}$ & $\begin{array}{l}\text { Gerakan Ahmadiyah, Gerakan MTA di Solo dan } \\
\text { Terorisme }\end{array}$ \\
\hline 8. Muhammadiyah & $\begin{array}{l}\text { Pembangunan } 3 \text { gereja di seputar alun-alun } \\
\text { Pancasila dan latennya kasus tanah Salib putih } \\
\text { sebagai peninggalan Belanda }\end{array}$ \\
\hline
\end{tabular}

\section{Kesimpulan}

Dengan paparan singkat di atas, ada catatan akhir yang hendak peneliti sampaikan, bahwa hubungan antaragama di Salatiga akan mengalami masa harmoni jika peran elit agama dapat memberikan ketenangan dan penjelasan secara teologis dan sosiologis kepada umatnya masing-masing secara terbuka dan dialogis. Namun hubungan antaragama dapat mengalami ketegangan jika terjadi ketimpangan sosial ekonomi, pendidikan, dan politik atas kelompok agama dan manajemen euphoria politik otonomi daerah yang tidak terkendali secara baik. Oleh sebab itu, masa depan hubungan antaragama di Salatiga memang tergantung pada gerakan keagamaan yang lebih santun dalam berwacana dan beretorika pada publik, dengan mengedepankan masalah-masalah yang riil dihadapi masyarakat ketimbang menghadirkan masalah-masalah yang tampak abstrak, tidak terjangkau sebab disitulah masyarakat agamaniah masih menghendaki agama yang mampu menjawab masalah riil di daerah. 


\section{Daftar Pustaka}

Abdullah., M. Amin. Dkk.. 2006.Metodologi Penelitian Agama: Pendekatan Multidisipliner.Yogyakarta: Lembaga Penelitian UIN Sunan Kalijaga.

Abdullah, Taufik. 1989.Metodologi Penelitian Agama: Sebuah Pengantar. Yogyakarta: PT. Tiara Wacana Yogya.

Ali, H.M. Sayuthi. 2002.Metodologi Penelitian Agama: Pendekatan Teori dan Praktek.Jakarta: PT RajaGrafindo Persada.

A'la Abd. Komaruddin SF, (Ed). 2002. Melampaui Dialog Agama. Jakarta: Penerbit Buku Kompas.

Alexander C. Jeffrey, Seidman Steven, (Ed). 1990. Culture And Society, Contemporary Debates. New York: Cambridge University Press.

Badan Litbang Agama Departemen Agama RI. 1981.Penelitian dan Pengkajian Agama di Indonesia: Arah, Kebijakan, Wilayah dan Pendekatannya.Jakarta: Balitbang Agama Depag RI.

Baehaqi, Imam (ed.). 2002. Agama dan Relasi Sosial, Menggali Kearifan Dialog, Yogyakarta: LkiS.

Bappeda Kota Salatiga. 2010. Profil Daerah Kota Salatiga Tabun 2008. Salatiga: Bapeda Kota Salatiga.

Denzin K. Norman, Lincoln S. Yvonna (Ed.). 1994. Handbook of Qualitative Research. London: SAGE Publication.

Kana, L. Nico. 2007. Penelitiaan Sosial Budaya Pendekatan dari dasar. Makalah Workshop Pencerahan Metodologi Penelitian. Salatiga: STAIN Salatiga.

Nugroho, Singgih. 2010. Menakar Kembali Tolerasi dan Intoleransi Agama di Jawa Tengah, Salatiga: Laporan Penelitian Percik.

Ridwan, M.Deden (Ed). 2001. Tardisi Baru Penelitian Agama Islam, Tinjauan Antardisiplin Ilmu. Bandung: Nuansa.

Sumardi, Mulyanto, dkk.,1982.Penelitian Agama: Masalab dan Pemikiran.Jakarta: Sinar Harapan.

http://id.wikipedia.org/wiki/Agama_di_Indonesia\#cite_note-indency-6 Turner S. Bryan. 1983. Religion and Social Theor. Second Edition, New Delhi.

Zulfa, M.. 2010. Ziarah Spritual Mewujudkan Kerukunan dan Toleransi Beragama: Studi Fungsional Pendidikan Agama Pada Beberapa SMA di Salatiga, STAIN Salatiga, Laporan Penelitian. 